\title{
Gomphus pulchellus Sélys, 1840 does not belong to the dragonfly (Odonata) fauna of the Czech Republic
}

Petr Jeziorski \& Otakar Holuša

Gomphus pulchellus Sélys, 1840 does not belong to the dragonfly (Odonata) fauna of the Czech Republic. - Čas. Slez. Muz. Opava (A), 60: 217-222.

Abstract: Gomphus pulchellus is an unacceptable record from the Czech Republic in the past. This deciscion is based on the revision of the material deposited in all major Czech and Slovak museums, on the revision of several other dragonfly collections, as well as on an extensive faunistic research carried out by the authors during the last twenty years. In addition, the published data were critically evaluated. In summary, no documented specimen in museums or private collections was found, and there are no recent records from the Czech Republic. Hence deletion of G. pulchellus from the species list of the Czech Republic is suggested. Reasons for the absence in the Czech Republic are discussed.

Keywords: Odonata, Gomphus pulchellus, check list, unacceptable record, faunistics, Czech Republic

\section{Introduction}

Gomphus pulchellus Sélys, 1840 is a west palearctic species, whose centre of occurrence lies in southwest Europe (Askew 2004, Dijkstra \& Lewington 2006, Clausnitzer 2007, Suhling \& Müller 1996), with good populations in Portugal, Spain, France and Switzerland (Seabra 1937, Aguiar \& Aguiar 1985, Maibach \& Meier 1987, Ocharan-Larondo 1987, Dommanget 1984, Monnerat 2005). It also occurs in the Netherlands and Belgium (Suhling \& Müller 1996) and its eastern border is in Germany where, towards the end of the $20^{\text {th }}$ century, it was recorded as extending its range north and east (Rudolph 1980). The most northeastern/eastern occurrences are known from Hannover (Schumann 1948), Würzburg (Eiseler \& Eiseler 1981) and Sachsen-Anhalt (Müller 1993), and in the eastern Nieder Sachsen it is abundant (Müller \& Suhling 1990). Its range has been extended into eastern Austria (Gächter 1988), where it currently occurs in Voralberg (Raab et al. 2006). Notable records of individual specimen have been recorded from northern Italy (Schneider \& Utzeri 1994) and Croatia (Schneider 1984). Currently it is considered to be extinct in Italy and of uncertain occurrence in Croatia (Clausnitzer 2007).

In the past, it was also recorded in two localities of the Danube in the Slovak Republic (Trpiš 1957, Dudich 1958) and also from Romania (Plattner 1968) and Bulgaria (Beschovski 1994). However, these findings are now considered doubtful (Askew 2004, Suhling \& Müller 1996).

Gomphus pulchellus inhabits all types of slow-flowing and standing waters and avoids strong currents. It is most common in slow, lowland rivers and their stagnant side channels, on residual floodplain pools and impoundments. In the north, it is usually found in gravel and sand pits, recreational lakes, oxbow lakes, fish ponds and canals but also occurs on sluggish rivers. The larvae occupy sandy patches, which may be covered with coarse detritus (Suhling \& Müller 1996).

\section{Published data}

Gomphus pulchellus was reported from the Czech Republic on the basis of a very improbable record (Flíček 2000), which was published without comment, without specifying the number of identified specimens, without stating the exact date (i.e. 1966 - 1970) and without an exact location ("complex south of Třeboň peatlands, bogs Branský les forest, Cepské blato peatbog, etc.") (Flíček 2000). Furthermore, it was published more than 30 years after being caught. In the last ten years the only reference made to this record appears to be that of Dolný (2007), who added further data (Cep village, Cepské rybníky ponds, $460 \mathrm{~m}$ above sea level, $10^{\text {th }}$ August 1967, 1 male, J. 
Flíček leg. et det., V. Teyrovský et J. Pudil rev., documentary specimen was later destroyed by store pests). Unfortunately, the occurrence of this species in the Czech Republic in this work was not critically evaluated (cf. Jeziorski \& Holuša 2008) and it was basically accepted as a species that has since disappeared from the region. However, in view of the above comments and the fact that it cannot be verified because it was not supported by a documented specimen, the record cannot accepted. New species for the fauna of any region should only be accepted when there is a verifiable specimen and precise details of location, etc. should be published.

In the lists of dragonflies of the Czech Republic (Teyrovský 1977; Jeziorski 1998; Hanel \& Zelený 2000) this species has never been cited. Neither was it included in the Red List of Threatened Species of the Czech Republic (Hanel et al. 2005). Searches have been made in some neighbouring countries, such as Slovakia (David 1996).

\section{Discussion and conclusion}

With respect to the recent knowledge of the species' distribution (Wendler \& Nüß 1994, Askew 2004, Dijkstra \& Lewington 2006, Clausnitzer 2007, Suhling \& Müller 1996) and to the revisions of material from all major Czech and Slovak museums (Perutík 1957, Straka 1990, Jeziorski \& Holuša 1999, Holuša 2000, 2002, Holuša \& Jeziorski 2002, 2007, Jeziorski 2007 , in prep.) and several others, and on the basis of an extensive faunal research carried out by both authors during the last few decades, and also by the wider public (Dolný 2007), the occurrence of $G$. pulchellus in the Czech Republic is improbable. At present, there are no documentary specimens in museum or private collections, and there are no recent records from the Czech Republic.

Since the record of $G$. pulchellus from the Czech Republic was published without an existing documented specimen, i.e. on the basis of unverified and unverifiable data, it cannot be regarded as a member of the odonate fauna of the Czech Republic. Until a fully documented specimen is found in the Czech Republic, it is necessary to delete this species from the dragonfly fauna of the Czech Republic and to classify it as a species that is potentially possible.

The occurrence in the Czech and Slovak Republics are mistaken for the following reasons:

a) false determination - Flíček (1980) probably exchanged species with cognate species of the genus Gomphus, namely for example with species Gomphus flavipes. Information that the specimen was revised by Vladimír Teyrovský and Josef Pudil is very doubtful. The specimen was presumably caught in 1967 but the scope and activities of Josef Pudil after 1938 are not known (Koleška 1998). Vladimír Teyrovský $(* 1898-\uparrow 1980)$ was active in publishing odonatological records and any revision of the status of this species would certainly be included in his checklist of dragonflies of the former Czechoslovakia (Teyrovský 1977).

b) geographical area of species - the centre of occurrence is located in Western Europe in Portugal, Spain and southern France, and extends into western Austria (Vorarlberg) and the eastern part of Germany, but probably never crossed through the border mountains of the Bohemian Massif in the Czech Republic and further east. In the past more than 100 years, this species has spread towards the northeast from the centre of its expansion in France (Rudolph 1980). In Austria, it was first recorded in 1985 (Gächter 1988). It is very improbable that this species occurred in the past in the Czech Republic (for example in 1967) since it would be a small area away from the main territory of occurrence.

c) improbable disappearance from an area in the Czech Republic - the species has not been detected in the area or elsewhere in the Czech Republic over the past 40 years, although it can be assumed that, due to changes in the landscape over the past 40 years, the species would have become extinct in the area eventually and also elsewhere in the Czech Republic. Due to intensive research it is very unlikely that there was a population in any other region of the country. 
d) lower vagility of imagoes - the species belongs to the suborder Anisoptera, whose representatives have far greater ability to "long" migration than species of the suborder Zygoptera. However, this species does not belong to the typical species with the ability for long-distance migration, such as Anax ephippiger (Burmeister, 1839), Anax parthenope (Sélys, 1839), Crocothemis erythraea (Brullé, 1832), Sympetrum fonscolombii (Sélys, 1840) and others (Corbet 1999). Thus it is very unlikely that this could have been a case of longdistance migration of this species with only a temporary occurrence in the Czech Republic. Nevertheless, with reference to the occurrence of G. pulchellus in Bavaria (ca $20 \mathrm{~km}$ from the border of the Czech Republic) (Kuhn 1998) and in west Austria (Raab et al. 2006) and present climatic changes (due to climatic changes mediterranean species extend to the north and east) possible finding of G. pulchellus in the west of the Czech Republic cannot be excluded in the future.

Based on the above, we do not considered the species to be a member of the dragonfly fauna of the Czech Republic. At present, we recommend that it be deleted from the checklist and considered only as a species potentially possible.

Acknowledgements: For their kindly permission to study respective odonate collections, we would like to thank the following: Ing. M. Bocáková, Ph.D. (employed in the Museum of National History in Olomouc at that time of the investigation), RNDr. L. Brabec (employed in the Regional Museum Valašsko in Valašské Meziříčí at that time of the investigation), $\uparrow$ RNDr. L. Brejcha (Šumperk), RNDr. P. Chvojka (National Museum, Praha), Mgr. Z. Kletečka (Regional Museum of Southern Bohemia, České Budějovice), Doc. RNDr. D. Kondělka, CSc. (Orlová), RNDr. P. Lauterer (employed in the Moravian Museum in Brno at that time of the investigation), RNDr. Petr Mückstein (employed at the Masaryk University, Natural Sciences Faculty in Brno at that time of the investigation), RNDr. J. Roháček, CSc. (Silesian Museum, Opava), RNDr. M. Roháčová, Ph.D. (Muzeum Beskyd, Frýdek-Místek), RNDr. D. Trávníček (Museum of South-Eastern Moravia, Zlín), RNDr. V. Uvíra, Ph.D. (Palacky University, Olomouc) and Ing. J. Vávra (Regional Museum, Ostrava). This paper was part of the research project „Strategy of the management of territories with a special protection status“ MSM 621564890204 of Faculty Forestry and Wood Technology of Mendel University in Brno.

\section{References}

Aguiar C. \& Aguiar S. (1985): Estudos odonatológicos em Portugal. Odonatos portuguêses. Odonatos africanos em Portugal. - Bol. Soc. Port. Ent. Suppl., 1: 245-267.

Askew R. R. (2004): The Dragonflies of Europe. 308 pp. Halley Books, Colchester.

Beschovski V. L. (1994): Comparatice zoogeographical review of Odonata fauna of Bulgaria (Insecta: Odonata). - Acta Zool. Bulg., 47: 3-15.

Clausnitzer V. (2007): Gomphus pulchellus. In: IUCN 2009. IUCN Red List of Threatened Species. Version 2009.2. Available at http://www.iucnredlist.org. Downloaded on 21 November 2009.

Corbet P. S. (1999): Dragonflies: Behaviour and Ecology of Odonata. 829 pp. Harley Books (B. H. \& A. Harley Ltd), Essex.

David S. (1996): Červený seznam a přehled druhů vážek Slovenské republiky. (Check list and Red list of the dragonfly of Slovak Republic). - Rosalia (Nitra), 11: 135-139.

Dijkstra K.-D. \& Lewington R. (2006): Field Guide to the Dragonflies of Britain and Europe. 320 pp. British Wildlife Publishing. Gillingham, Dorset.

Dolný A. (2007): Gomphus pulchellus Sélys, 1840 - klínatka západní. pp. 436-437. - In: Dolný A., Bárta D., Waldhauser M., Holuša O., Hanel L. et al. 2007: Vážky České republiky: Ekologie a ochrana rozšíření. (The Dragonflies of the Czech Republic: Ecology, Conservation and Distribution). 672 pp. Český svaz ochránců prírody, Vlašim.

Dommanget J.-L. (1984): Atlas préliminaire des Odonates de France. Etat advancement au 31/12/93. 92 pp. Secrétariat de la Faune et dela Flore, Paris.

Dudich E. (1958): Die Grundlagen der Fauna eines Karpaten-Flusses. - Acta zool. Hung., 3:179-200.

Eis eler B. \& Eiseler F. (1981): Markierungsergebnisse bei Gomphus pulchellus. - Libellula, 1 (1): 29-31.

Flíček J. (2000): Současný stav inventarizačního průzkumu vážek rašeliništ' povodí Lužnice. (A current state of the knowledge of the dragonflies (Odonata) of peat bogs around the river Lužnice (Southern Bohemia)), pp. 60-65. In: Hanel L. [ed.]: Sborník referátů III. celostátního semináře odonatologů v CHKO Třeboňsko 2000. 192 pp. - ZO ČSOP Vlašim. 
Gächter E. (1988): Gomphus pulchellus Sélys 1840 - neu für Österreich (Anisoptera: Gomphidae). - Notul. odonatol., 3 (1): 6-8.

Hanel L., Dolný A. \& Zelený J. (2005): Odonata (vážky). pp. 125-127. In: Farkač J., Král D. \& Škorpík M. [eds.]: Červený seznam ohrožených druhů České republiky. Bezobratlí. (List of threatened species in the Czech Republic. Invertebrates). 760 pp. Agentura ochrany př́rody a krajiny ČR, Praha.

Hanel L. \& Zelený J. (2000): Vážky (Odonata): výzkum a ochrana. 240 pp. Český svaz ochránců př́rody, Vlašim.

Holuša O. (2000): Vážky (Insecta: Odonata) ve sbírkách Muzea Beskyd Frýdek-Místek (Česká republika). (The dragonflies (Insecta: Odonata) in the collections of the Museum of the Beskydy Mts Frýdek-Místek (Czech Republic)). - Klapalekiana, 36: 71-79.

- (2002): Vážky (Insecta: Odonata) ve sbírkách Př́rodovědecké fakulty Masarykovy Univerzity v Brně (Česká republika). (Dragonflies (Insecta: Odonata) in the collection of the Fakulty of Science of Masaryk University Brno (Czech Republic)). - Sborník Př́rodovědného klubu v Uh. Hradišti, 7: 140-144.

Holuša O. \& Jeziorski P. (2002): Sbírka vážek (Insecta: Odonata) v Moravském zemském muzeu v Brně (Česká republika). (The collection of dragonflies (Odonata) in the Moravian Museum in Brno (Czech Republic)). - Sborník Př́rodovědného klubu v Uh. Hradišti, 7: 145-152.

- (2007): Sbírka vážek (Odonata) v Ostravského muzea. (Collection of dragonflies in Museum of Ostrava). Práce a Stud. Muz. Beskyd (Př́r. Vědy), 19: 143-150.

Jeziorski P. (1998): Check list of dragonflies (Odonata) of the Czech republic. - Čas. Slez. Muz. Opava (A), 47: 173-177.

- (2007): Collection of dragonflies (Odonata) in the Museum of National History in Olomouc and in the Regional Muzeum Valašsko in Valašské Meziř́čí. (Sbírka vážek (Odonata) Vlativědného muzea v Olomouci a Muzea regionu Valašsko ve Valašském Meziříčí). - Čas. Slez. Muz. Opava (A), 56: 145-148.

- (in prep.): Sbírka vážek (Odonata) Lubomíra Brejchy v Národním muzeu, Praha. (Collection of dragonflies (Odonata) of Lubomír Brejcha in the National Muzeum in Prague).

Jeziorski P. \& Holuša O. (1999): Collection of dragonflies (Odonata) in Museum jihovýchodní Moravy in Zlín. (Sbírka vážek (Odonata) Muzea jihovýchodní Moravy ve Zlíně). - Sborník Př́rodovědného klubu v Uh. Hradišti, 4: 103-106.

Jeziorski P. \& Holuša O. (2008): Coenagrion mercuriale (Charpentier, 1840) does not belong to the fauna of dragonflies (Odonata) of the Czech and Slovak Republics. - Čas. Slez. Muz. Opava (A), 57: 149-154.

Koleška Z. (1998): Seznam bibliografií československých entomologů (entomologové nežijící) II. Dodatky, doplňky a opravy biografických hesel „Seznamu bibliografií československých entomologů (entomologové nežijící) I“"ve svazcích 1-15 z let 1979-1995. - Klapalekiana, 34 (Suppl.): 1-238.

Kuhn K. (1998): Westliche Keiljungfer (Gomphus pulchellus Sélys, 1840). pp. 110-111. In: Kuhn K. \& Burbach K. (1998): Libellen in Bayern. 336 pp. Verlag Eugen Ulmer GmbH \& Co., Stuttgart.

Maibach M. \& Meier C. (1987): Verbreitungsatlas er Libellen der Schweiz (Odonata). 229 pp. Centre Suisse de Cartographie de la Faune, Neuchâtel.

Monnerat C. ( 2005): Gomphus pulchellus Selys, 1840 (Westliche Keiljungfer - Gomphe joli). pp 176-179. In: Wildermuth H., Gonseth Y. \& Maibach A.: Odonata - Die Libellen der Schweiz. Fauna Helvetica 12. 400 pp. - Centre Suisse de Cartographie de la Faune, Schweizerische Entomologische Gesellschaft, Neuchâtel.

Müller J. (1993): Rote Liste der Libellen der Landes Sachsen-Anhalt. - Ber. Landesamt Sachsen-Anhalt, 9: 1316.

Müller L. \& Suhling F. (1990): Verbreitung und Ökologie der Westlichen Keiljungfer Gomphus pulchellus Sélys, 1840, in Südostniedersachsen (Odonata: Gomphidae). - Braunschw. Naturk. Schr., 3: 655-667.

Ocharan-Larondo F. J. (1987): Los odonatos de Asturias y de Espana: aspectos sistematicos y faunisticos. 983 pp. - Dissertation, Oviedo.

Perutík R. (1957): Sbírka vážek Slezského musea v Opavě (Odonata). (Die Sammlung von Wasserjungfern im Schlesischen Museum in Opava (Odonata)). - Čas. Slez. Muz. Opava (A), 6: 3-10.

Plattner H. (1968): Bemerkungen über die Larven und Exuvien der Odonaten Ramäniens. - Faun. Abh. Staatl. Mus. Tierk. Dresden, 7: 51-60.

Raab R., Chovanec A. \& Pennerstorfer J. (2006): Libellen Östereichs. 350 pp. Umweltbundesamt, Wien, SpringerWienNewYork.

Rudolf R. (1980): Die Ausbreitung der Libelle Gomphus pulchellus Sélys 1840 in Westeuropa. - Drosera, 80 (2): 63-66.

Schneider. W. (1984): Zum Nachweis von Gomphus pulchellus Selys 1840 in Jugoslawien (Odonata: Anisoptera: Gomphidae). - Ent. Z. Frankfurt a. M., 94 (8): 109-111.

Schneider W. \& Utzeri C. (1994): Gomphus pulchellus Sel. new to the Italian Odonata fauna (Anisoptera: Gomphide). - Notul. odonatol., 4(4): 72-73.

Schumann H. (1948): Bemerkenswerte Libellen aus Niedersachsen. - Beitr. Naturk. Niedersachsen, 2: $27-32$. 
Seabra A. F. De (1937): Notas sôbre os Odonatos de Portugal. - Mem. Estud. Mus. Zool. Univ. Coimbra, 7: 144.

Straka V. (1990): Vážky (Odonata) Slovenska. - Zbor. Slov. nár. Múz., Prír. Vedy, 36: 121-147.

Suhling F. \& Müller O. (1996): Die Flussjungfern Europas. 240 pp. Die Neue Brehm-Bücherei, 628, Magdeburg: Westarp-Wiss.; Heidelberg: Spektrum Akad. Verlag.

Teyrovský V. (1977): Odonata, pp. 31-33. In: Dlabola J. (ed): Enumaratio Insectorum Bohemoslovakiae. Check List Tschechoslowakische Insektenfauna. - Acta faun. ent. Mus. Nat. Prague, 15 (Suppl. 4): 5-158.

Trpiš M. (1957): Predbežný prehl’ad vážok (Odonata) Žitného ostrova. - Biológia (Bratislava), 12: 433-449.

Wendler A. \& Nüß J.-H. (1994): Libellen. 129 pp. Deutscher Jugendbuch für Naturbeobachtung, Hamburg.

\section{Gomphus pulchellus Sélys, 1840 není součástí fauny vážek (Odonata) České republiky}

Gomphus pulchellus Sélys, 1840 je západopalearktický druh, jehož centrum rozšíření leží v jihozápadní Evropě (Askew 2004, Dijkstra \& Lewington 2006, Clausnitzer 2007, Suhling \& Müller 1996). Druh se vyskytuje v početných populacích na území Portugalska, Španělska, Francie a Švýcarska (Seabra 1937, Aguiar \& Aguiar 1985, Maibach \& Meier 1987, Ocharan-Larondo 1987, Dommanget 1984, Monnerat 2005). V areálu se nachází take území Nizozemí a Belgie (Suhling \& Müller 1996). Východní hranice rozšǐření leží na území Německa, ke konci 20. století bylo pozorováno rozšiřování areálu směrem na sever a východ (Rudolph 1980). Nejseverovýchodnější výskyt je znám od Hannoveru (Schumann 1948) a Würzburgu (Eiseler \& Eiseler 1981), až po Sachsen-Anhalt (Müller 1993), ve východním Dolním Sasku je zjišt’ován jako velmi početný (Müller \& Suhling 1990). Rozšiřrení areálu bylo zjištěno i na území západního Rakouska (Gächter 1988), kde se v současnosti vyskytuje ve spolkové zemi Voralberg (Raab et al. 2006). Nálezy jednotlivých dospělcủ pocházejí z oblasti severní Itálie (Schneider \& Utzeri 1994) a Chorvatska (bývalá Jugoslávie) (Schneider 1984). Z území Itálie a Chorvatska je v současnosti hodnocen jako nejistý (Clausnitzer 2007).

Historicky je uváděn take ze dvou lokalit v Podunajské nížině na Slovensku (Trpiš 1957, Dudich 1958), také z oblasti Rumunska (Plattner 1968) a Bulharska (Beschovski 1994). V současnosti jsou tyto nálezy hodnoceny jako velmi pochybné popř. byly negovány (Askew 2004, Suhling \& Müller 1996).

Gomphus pulchellus je z Česka uváděn na základě publikování nedokladovaného nevěrohodného nálezu (Flíček 2000). Tento nález byl publikován bez jakéhokoliv komentáře, bez uvedení počtu zjištěných exemplářu, bez přesného data nálezu (uvedeno v letech 1966 - 1970) a bez přesné lokality (uvedeno „komplex rašeliništ’ jižně od Třeboně, rašeliniště Branský les, Cepské blato atd.“). Tento nález byl opublikován po více jak 30 letech od chycení exempláře $\mathrm{v}$ terénu. Zrèejmě vzhledem $\mathrm{k}$ opublikování tohoto nálezu v nerecenzovaném sborníku a bez konkrétních informací, byl tento nález téměř 10 let opomíjen. Teprve až Dolným (Dolný 2007) byl tento nález doplněn dalšími údaji (Cep, Cepské rybníky, 460 m n. m., 10.VIII.1967, 1 samec, J. Flíček leg., det., V. Teyrovský et J. Pudil rev., dále je uvedeno ,..dokladový exempláŕ byl později zničen skladištními škůdci“). Bohužel výskyt tohoto druhu $\mathrm{v}$ České republice nebyl $\mathrm{v}$ této práci kriticky vyhodnocen a byl $\mathrm{v}$ podstatě akceptován jako druh pro území vymizelý, přestože tento nepravděpodobný nález nebyl podložen existencí dokladového exempláře (cf. Jeziorski \& Holuša 2008).

Vzhledem $\mathrm{k}$ výše uvedenému je publikovaný údaj neověřný a neoveřitelný, tedy neakceptovatelný. Nové druhy pro fauny určitého území by měly být $\mathrm{v}$ pojetí moderní faunistiky publikovány pouze na základě dokladovaného materiálu nebo na základě ověřitelného údaje nebo skutečnosti.

V seznamech vážek České republiky (Teyrovský 1977; Jeziorski 1998; Hanel \& Zelený 2000) tento druh nikdy nebyl uváděn. Tento druh není uveden ani v Červeném seznamu ohrožených druhů České republiky (Hanel et al. 2005).

Vzhledem k současným znalostem rozšíření druhu (Wendler \& Nüß 1994, Askew 2004, Dijkstra \& Lewington 2006, Clausnitzer 2007), studia materiálu všech větších muzeí na území bývalého Československa (Perutík 1957, Straka 1990, Jeziorski \& Holuša 1999, Holuša 2000, 2002, Holuša \& Jeziorski 2002, 2007, Jeziorski 2007, in prep.) a několika dalších sbírek a na rozsáhlém faunistickém výzkumu prováděném oběma autory v posledních desetiletích, ale i široké veřejnosti (Dolný 2007) je výskyt $G$. pulchellus na území Česka nepodložený.

Vzhledem k tomu, že velmi nepravděpodobný výskyt $G$. pulchellus z České republiky byl publikován bez existujícího dokladového exempláré, tedy na základě neověřeného a neověřitelného údaje, nelze považovat tento druh za člena fauny České republiky. Dokud nebude druh G. pulchellus doložen dokladovým materiálem z České republiky je nutné tento druh ze seznamu fauny vážek České republiky vypustit a v současné době jej považovat za druh pouze jako možný.

Údaj o výskytu druhu na území České republiky je možné považovat za mylný z několika důvodů:

a) chybná determinace - Flíček (1980) mohl zaměnit tento druh s prŕibuzným druhem rodu Gomphus, a to např. s druhem Gomphus flavipes. Informace, že předmětný exemplář revidoval Vladimír Teyrovský a Josef Pudil se zdá velice pochybná. Předmětný exemplár měl být uloven v roce 1967, ale o působnosti a činnosti Josefa Pudila po roce 1938 není nic známo (Koleška 1998). V. Teyrovský (*1898 - †1980) byl publikačně činný 
a v př́padě revize tohoto druhu by zajisté tento druh zařadil do svého seznamu vážek check listu bývalého Československa (Teyrovský 1977).

b) geografický areál druhu - těžiště areálu leží v západní Evropě v oblasti Portugalska, Španělska a jižní Francie, na východ areál v současné době zabíhá až do Rakouska a východní části Německa, ale pravděpodobně nikdy nezasahoval přes pohraniční pohoří Českého masívu do České republiky a dále na východ. V posledních více jak 100 letech se tento druh šiří směrem na severovýchod od centra jeho rozšíření ve Francii (Rudolph 1980). V Rakousku byl poprvé zjištěn až v roce 1985 (Gächter 1988) a to v jeho západní části. Vzhledem k tomu je velmi nepravděpodobné, že by druh na území ČR měl v minulosti (např. už v roce 1967) v rámci areálu malou arelu daleko od hlavního areálu.

c) nepravděpodobný zánik arely popř. vyhynutí na území ČR - za posledních cca 40 let nebyl v dané oblasti, ani jinde na území ČR, druh zjištěn. I když lze předpokládat nemalé ovlivnění krajiny za posledních 40 let, druh by musel vyhynout $v$ dané oblasti popř. i jiných oblastech ČR. Vzhledem k intenzivnímu průzkumu je velmi nepravděpodobné, že by se v jiných oblastech nezachovala ani jediná jiná populace.

d) nižší vagilita dospělců - druh patří do podřádu Anisoptera, jehož zástupci mají daleko větší schopnosti “dálkových” migrací než zástupci Zygoptera. Nicméně tento druh nepatří k typickým druhům se schopností dálkových migrací jako např. druhy Anax ephippiger (Burmeister, 1839), Anax parthenope (Sélys, 1839), Crocothemis erythraea (Brullé, 1832), Sympetrum fonscolombii (Sélys, 1840) a další (Corbet 1999). Vzhledem k tomu je velice nepravděpodobné, že by se jednalo u tohoto druhu o dálkovou migraci pouze $\mathrm{s}$ dočasným výskytem na předmětné lokalitě.

Nicméně vzhledem k výskytu G. pulchellus na území Bavorska (cca 20 km od hranice z Českou republikou) (Kuhn 1998) a v západní části Rakouska (Raab et al. 2006) a také ke klimatickým změnám, kdy se vlivem těchto změn šíŕi mediteránní druhy na sever a na východ, nelze v budoucnu výskyt tohoto druhu vyloučit na západním území České republiky. Tento nález je však nutno doložit dokladovým materiálem.

Na základě výše uvedeného, nepovažujeme druh Gomphus pulchellus za člena fauny vážek na území České republiky. V současné době doporučujeme vypustit jej ze seznamu druhů a chápat jej pouze jako druh potenciálně možný.

Authors' addresses: Petr Jeziorski, Na Bělidle 1, CZ-735 64 Havířov-Suchá, Czech Republic; e-mail: jezirko@post.cz Otakar Holuša, Department of Forest Protection and Wildlife Management, Faculty of Forestry and Wood Technology, Mendel University in Brno, Zemědělská 3, CZ-61300 Brno; e-mail: holusao@email.cz 